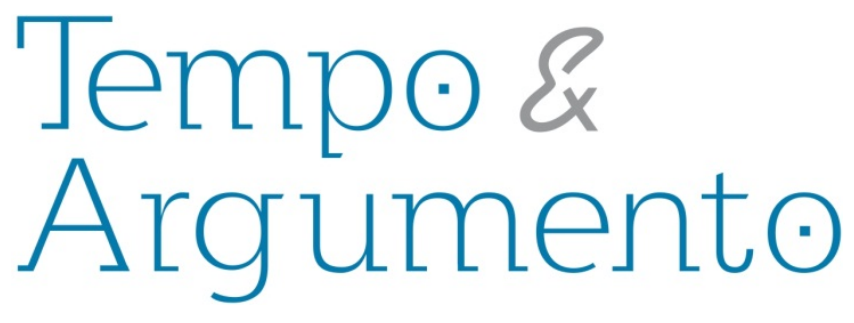

\title{
Pasta Bergery: uma trajetória política na história recente da frança
}

\section{Resumo}

Gaston Bergery, nascido em 1892 e falecido em 1974, foi advogado e político francês. De editor de política da revista La Flèche a embaixador na Turquia durante o governo de Vichy. Busca-se, através da análise de cartas, artigos e outros documentos pessoais e públicos, traçar a trajetória deste indivíduo politicamente atuante durante a primeira metade do século XX. Para isto foi feita uma extensa pesquisa por diversos arquivos entre os quais o do Castelo de Vincennes (arquivo do exército), do Cais de Orsay (arquivos do Ministério dos Assuntos Estrangeiros), os Arquivos Nacionais, da fundação Hoover, da Universidade de Yale, bem como algumas entrevistas orais.

Palavras-chave: Arquivos. Regime de Vichy. Diplomacia. Gaston Bergery.

\section{Yves Pourcher}

Professor da Universidade de

Toulouse Le Mirail - França. yves.pourcher@sciencespo-toulouse.fr

\section{Fernando Coelho}

Mestre em Estudos da Tradução e doutorando em Linguística na

Universidade Federal

de Santa Catarina

zeffiretto@gmail.com

\section{Para citar este artigo:}

POURCHER, Yves. Pasta Bergery: uma trajetória política na história recente da frança.

Revista Tempo e Argumento. Florianópolis, v. 5, n.9, jan./jun. 2013. p. 405 - 432.

DOI: $10.5965 / 2175180305092013405$

http://dx.doi.org/10.5965/2175180305092013405 


\title{
The Bergery file: a political trajectory in the recent history of France
}

\begin{abstract}
Gaston Bergery was born in 1892 and died in 1974. He was a lawyer and a French politician. From editor of the political magazine La Flèche, he became the ambassador in Turkey during the Vichy government. We aim to, through the analysis of letters, articles and other personal and public documents, trace the trajectory of this individual, who was politically active during the first half of the twentieth century. To this, we have made an extensive research through several files, including that of the Castle of Vincennes (the Army file), the Quais d'Orsay (the Ministry of Foreign Affairs files), the National Archives, the Hoover Foundation, Yale University, as well as some oral interviews.
\end{abstract}

Keywords: Archives. Vichy Regime. Diplomacy.

Gaston Bergery. 
Foi a ideia da passagem que se impôs pouco a pouco. Mal uma porta se fechava e outra se abria, com um novo caminho que eu deveria de todo modo percorrer. Dizendo isto, não recorro a uma evocação poética fácil e não me lanço de modo nenhum a uma recomposição eivada de nostalgia. Eu vivi esta errância, e dificilmente. Avançando sem cessar, eu sentia esta impossibilidade de atingir o objetivo traçado. Devo confessar hoje e reconhecer o que não é de maneira alguma um fracasso, mas uma corrida trabalhosa semeada de obstáculos. Tudo isto para tentar avançar na história na busca de um personagem esquecido. A propósito dele, guardei essencialmente uma sucessão de lugares em que eu juntava relatórios, cartas, discursos e fotos. Para compor os contornos trêmulos do seu retrato, escolhi voluntariamente reter-lhe extratos, copiando-os. Melhor do que qualquer outro comentário ou análise, eles revelam a ambiguidade do personagem e a inquietação da época que ele atravessou. Desordem das ideias, paradoxo das situações com crentes e renegados, e depois este barulho ensurdecedor das botas que anunciava a guerra. Imagens desfilavam. Elas repercutiam em minha cabeça.

Bem no início, eu comecei com uma definição geral dos arquivos. "Coleção de papeis, títulos, documentos, dossiês antigos", estava marcado no meu dicionário. Eu retinha dela esta ideia de um tempo passado, dissimulado, evadido e, talvez, completamente esquecido. E depois, muito rápido, surgiu o interesse por sua cor. Arquivos diurnos, noturnos, os do claro-escuro, do cinza mais que do branco?

O sombrio impôs-se. A que ele correspondia? Eu buscava o seu sentido. "Que é pouco iluminado, que recebe pouca luz (ver preto, escuro), está escrito. Que é misturado com preto, ou aproxima do preto. Cor, tom sombrio."

Eu continuava e encontrava nuanças: "Cujos pensamentos, sentimentos são eivados de tristeza, de abatimento, de dor ou de inquietude. Ver amargo, mesto, moroso, taciturno, tenebroso, triste.

De uma tristeza trágica, ameaçadora. Ver sinistro. Ver atrabiliário, bilioso, melancólico, pessimista.

De uma tristeza trágica ou ameaçadora. Ver fúnebre, funesto, inquietante, sinistro, trágico. 
Deplorável, lamentável."

Soava como um julgamento. "Foi lamentável!", eu ouvia ecoar. Então eu vasculhava a minha galeria de retratos e me deparava com vários desses indivíduos sombrios que tinham aparecido no entreguerras e tinham desaparecido durante a Ocupação. Entre eles, eu buscava um personagem de grande envergadura, com uma magnífica carreira promissora, anunciada, e depois um naufrágio total e definitivo. Eu o encontrava finalmente, e seguia os jogos de luz que pouco a pouco se lançavam sobre os seus passos. Uma silhueta se desenhava, ontem iluminada, hoje apagada e até mesmo rejeitada. Para contar a sua vida, eu devia explorar os lugares em que eram disseminados os traços de seus gestos e de suas palavras. Nada mais que pontas e pedaços talhados.

Fui a vários endereços. Eu entrava, sentava-me, abria caixas. Nos maços de documentos, eu achava a revelação, a ambição, o sucesso. Então eu me obstinava e continuava. A noite caía, rápida, brutal. Falhas, fracassos, comprometimentos, falência e morte: tudo estava lá. O arquivo murmurava.

Ele começou por ser aquele a quem todas as esperanças eram permitidas, o homem que vem, que se espera e se admira antes de se tornar aquele que cai, e do qual não resta senão, - e somente para raras testemunhas, - a lembrança da passagem, a do meteoro. Entretanto ontem, durante todos esses anos, ele brilhou muito.

Para falar bem dele, eu lia livros e vasculhava mais uma vez essas pilhas de arquivos que, inexoravelmente, se misturavam e se superpunham. Era o arquivo mina, disperso, esmigalhado e colorido. Eu o encontrava e exumava-Ihe os fragmentos. Mas eu via também que havia todo o resto, o arquivo escondido, afastado, reservado, fechado. Aquele que eu não atingia e que talvez nunca chegaria a atingir. Então, com medo de ser incompleto, eu me afastava e me voltava a outra direção. Explorava para tentar mais uma vez aproximar-me dele e dizer enfim quem ele foi. Eu buscava indícios sobre a sua personalidade. Em vez de acumular e ler documentos neutros ou distantes, eu queria discerni-lo rapidamente, vê-lo, escutar raras e preciosas testemunhas que subsistiam. 


\section{Esboço biográfico}

Mas quem se lembra dele? Sua vida parece definitivamente perdida. Ele faz parte deste pequeno grupo de homens brilhantes, nos quais alguns acreditaram tanto, e que caíram no esquecimento da história. Aquele que eu escolhi não era conhecido de alguns historiadores. Seu nome, Gaston Bergery. O resumo de sua carreira está escrito brevemente em sua ficha. Por exemplo, aquela que ele tinha constituído para a edição de 1973-1974 do Who's who. Eram linhas que ele tinha escrito com as palavras que ele tinha escolhido para se apresentar.

Eu as transcrevo em parte:

“Bergery (Gaston, Frank), advogado honorário, ex-deputado. Nascido em 22 de novembro de 1892 em Paris. Divorciado da primeira esposa, nascida Germaine Malançon, e depois da segunda, nascida Lubov Krassine (filha de Leonid Krassine (1870-1926), embaixador da URSS na França) (1 filho: Jean-François); casado novamente em 5 de agosto de 1934 com Elisabeth-Charlotte Shaw-Jones. Formação: Lycée Carnot e Faculdade de Letras de Paris, Faculdade de Direito.

Carreira: Secretaria da conferência da Paz (1918), secretário geral adjunto interaliado à Comissão das Reparações (1918-1924), chefe de gabinete do ministro dos Assuntos Estrangeiros (1924-1925), deputado de Seine-et-Oise (1928-1934 e 1936-1940), conselheiro geral de Seine-et-Oise (1928-1942), embaixador em Moscou (1941) e depois em Ancara (1942-1944); retomou (1947) seu posto na advocacia de Paris, com a mesma especialização em direito internacional. Advogado honorário (desde 1965).

Obras: artigos diversos na imprensa; garantiu sobretudo a rubrica política da revista La Flèche (1934-1939). Dois livros: Air Afrique, Voie impériale (1937) e (sob o pseudônimo de Gaston François) La Vierge et le Sagittaire (1948)."

Ele recebera várias condecorações.

Seu endereço: rua de Bourgogne, 29, Paris $\left(7^{\circ}\right)$. 
Para ir além desta breve exposição, eu busquei e encontrei um livro que refazia, em grande medida, o seu percurso. Seu autor é Philippe Burrin, um historiador suíço especialista no período. O título: La dérive fasciste. Doriot, Déat, Bergery 1933-1945

Burrin completou inutilmente os dados do anuário dos poderosos. Assim, eu fiquei sabendo que durante a guerra de 1914-1918, Gaston Bergery fora ferido no fronte de Champagne. Após esse conflito, ele viajou a negócio para Londres e Istambul. Visitou também a União Soviética e os Estados Unidos. Casou-se três vezes, frequentou os salões e os surrealistas em companhia de Emmanuel Berl e de Pierre Drieu La Rochelle. Este dândi frio, provocador e solitário, era também um homem de partido ativo e terrivelmente sério. Queria acima de tudo o sucesso. Seus contemporâneos tinham sublinhado sua frieza, sua ironia e seu cinismo. Para servir à sua causa e aos seus interesses políticos, ele fundou um jornal, o La Flèche, cuja tiragem em 1937 era em torno de 25000 e 30000 exemplares. Após a derrota de 1940, ele se colocou a serviço do marechal Pétain. Bergery esperava então tomar o poder. No mês de fevereiro de 1949, ele foi julgado pela Corte de Justiça do Sena. Seu processo foi, aliás, o único aberto contra um embaixador de Vichy.

Tudo estava lá, dito em algumas linhas: a ambição, a espera, a queda. Mas faltavam a meu quadro carne e cores. Eu desejava ir mais longe. Mas quem era Gaston Bergery? Como o viam aqueles que Ihe foram próximos.

\section{O ambicioso}

O primeiro que eu quero citar é o escritor jornalista Maurice Martin du Gard. No número dos meses de julho e agosto de 1936 de La Revue de Paris, ele compôs um retrato que sublinhava a postura, o temperamento, a novidade, o paradoxo Bergery. Para ele, este homem era um mistério, uma incógnita, quase um desafio. "É pouco dizer, escreve ele, que Gaston Bergery não tranquiliza. Ele zomba disso. Acostumar-nos-emos, ele deve

\footnotetext{
${ }^{1}$ Philippe Burrin, La dérive fasciste. Doriot, Déat, Bergery 1933-1945 (Paris : Seuil, 1986). Ver também de Diane N. Labrosse, «"La Dérive Bergery/The Bergery Drift": Gaston Bergery and the Politics of Late Third Republic France and the Early Vichy State », Historical Reflections 34, 2 (2008), 66-87.
} 
"Pergunta-se às vezes, acrescenta Martin du Gard, se Gaston Bergery é um homem de futuro. Eu poderia responder que ele o é até mesmo um pouco demais, pois está sempre adiantado de uma ideia e de um fato, de um fato que conta pelo menos na vida internacional." Depois ele concluiu: "Flutua em torno desta figura um não sei quê de dramático e de misterioso. No paletó de um bom tecido azul que, cruzado até o pescoço, mal deixa ver a roupa de baixo, o cabelo curto, a palavra afiada, certamente, não é uma jovem estrela de teatro. Ele está lá, magro e reto, entre seus livros."

Para Martin du Gard, Gaston Bergery esperava a sua hora. Ao lado dos notáveis muito bem nutridos do grande partido radical ao qual ele pertenceu por muito tempo, ele aparecia já como um homem novo em política. Magro, esportivo, pronunciando frases curtas, ele era para alguns "a esperança da nossa geração", assim como escreveu Bertrand de Jouvenel, outro jornalista engajado que, ele também, desaparecerá na política de Colaboração. Este último notou igualmente a postura do personagem, suas roupas esportivas, a distinção de um simples cordão de couro amarrado em torno do pescoço. Em face da terrível incerteza desses anos do entreguerras, Bergery era "o homem que vem"2.

Como outros que o precederam ou que o seguirão - assim como o jovem François Mitterrand em relação ao escritor François Mauriac - Gaston Bergery era um verdadeiro personagem de romance. Ele serviu, aliás, de modelo a um romancista que, igualmente, se comprometerá durante os anos negros da Ocupação. Sob a pluma de Drieu la Rochelle ${ }^{3}$, Bergery se torna este ambicioso chamado Clérences, cuja vontade de se dar bem parece inscrita nos seus genes. "Durante todo o jantar, escrevia Drieu ${ }^{4}$, ele falou da ambição como de uma coisa óbvia e que o colocava, e talvez a Gilles, acima da maior

\footnotetext{
${ }^{2}$ Bertrand de Jouvenel, Un voyageur dans le siècle (Paris : Robert Laffont, 1979).

${ }^{3}$ Pierre Drieu La Rochelle, Gilles (Paris : Gallimard, 1939).

${ }^{4}$ Drieu La Rochelle, Gilles, 178.
} 
parte das contingências humanas." O chamado Clérences encarnava já muitas esperanças. "Gilles meditava sobre a carreira e sobre o caráter de Clérences, conta Drieu. Não tinha ele bastantes e diversas qualidades para tornar-se o homem que concentraria as forças dos homens de sua idade??" "Tens tu a essência de um apóstolo?” ele Ihe perguntou enfim. A história se acelerava. Ela ia tornar-se louca. À margem do seu caminho, Bergery tripudiava.

\section{Jovens fiéis}

São muitos os que se lembram dele falando com um quê de nostalgia dos seus encontros. Filho de escritor prestigiado, e ele próprio escritor, Claude Mauriac contou nas suas memórias a importância que tinha tido para ele este personagem. Ele era então um jovem rapaz adepto do frontismo, movimento e pensamento políticos de Bergery, que, naquele tempo de perigos, rejeitava os dois extremos, o comunismo e o fascismo. Para compreender bem a força e a sedução deste pensamento e do que ele encarnava, é preciso citar longamente Mauriac, que, na sua imensa obra Temps Immobile, não cessa de vasculhar o passado. Ele estira, dispersa o tempo colhendo aqui e ali momentos que ele encadeia. Arbitrariamente, eu reconstruo a cronologia de suas relações com Bergery. Sua história comum tinha começado antes da guerra.

No domingo de 4 de dezembro de 1938, em Paris, Mauriac foi a uma reunião política do movimento: “Em casa de Vianet, cais da Rapée, banquete de La Flèche. Em torno de trezentas pessoas. (...) Discurso de Bergery, que os correios do Estado retransmitem. De onde estou, eu o vejo bem, muito pálido no seu eterno terno preto (colarinho branco, gravata preta). Ele lê, e o papel treme em suas mãos. Parece emocionado. Não está acostumado, é visível, com o microfone. E mais, a sensação de ser ouvido por franceses que não o conhecem o intimida. Ele gostaria tanto de trazê-los para a sua causa através do prestígio da sua voz. Jean Maze fala em seguida, mas não se revela um grande orador. Seu órgão, fraco demais, não suporta. E assim o escutam com menos

\footnotetext{
${ }^{5}$ Drieu La Rochelle, Gilles, 535.
} 

Bourgogne, n. 29, em casa de Bergery, onde ele era esperado: "O terno preto seria uma coqueteria política, o equivalente discreto de algum tipo de uniforme? Bergery não aparece pela primeira vez em completo marrom, gravata vermelha..."

Mauriac olhou e escutou aquele em quem acreditava, ao mesmo tempo em que mantinha o seu senso crítico: "Bergery, cuja inteligência é tão aguda, deixa-se contudo contaminar por algumas ingenuidades. Assim, quando me falou naquela tarde do efeito surpreendente que produziu o discurso que ele fez ao microfone, depois do banquete da outra noite: "Os aplausos e as aclamações pareciam nascer de uma grande multidão. Assemelhava-se, parece, ao rumor do Sport-Palace." É sem a menor ironia que ele evoca os fastos hitlerianos! Ele se deixa levar também pelas ilusões da T.S.F."”

Após a derrota, Bergery se compromete definitivamente, excluindo-se da história e tornando-se uma sombra. Mauriac o revê bem mais tarde, em Paris, na segunda-feira de 29 de junho de 1953. "Na multidão de um coquetel, conta ele, em casa de Marie-Blanche de Polignac, este homem gasto, que se faz notar apenas por sua camisa azul, Gaston Bergery, com todo o seu prestígio apagado, homem sem futuro, apenas com seu passado perdido. Uma velha ternura em mim por ele, e que faz que eu o escute com respeito, para grande surpresa de minha mulher, falando com a dureza da juventude: - Com seu passado ninguém se importa... Eu não, à medida que este passado foi também o da minha geração - e o meu, o mais pessoal. Ele fala com o brilhantismo de outrora - mas que já não brilha. Era preciso a noite que fazia em torno dele a sua lenda. Restam paradoxos cuja gratuidade e inutilidade são as únicas sensíveis. Resta um homem que não mostra o seu cansaço: ele está sobrecarregado de trabalho (no Palácio), mas de um trabalho que não o interessa... E, com efeito, para quem gostaria de estar (e poderia ter estado) à frente dos negócios..."

\footnotetext{
${ }^{6}$ Claude Mauriac, Le Temps Immobile 6. Le rire des pères dans les yeux des enfants (Paris : Grasset, 1981 ), 35.

${ }^{7}$ Mauriac, Le Temps Immobile 6. Le rire des pères dans les yeux des enfants, 38-39.
} 
Alguns dias depois, no domingo de 5 de julho de 1953, Mauriac janta em casa de Bergery. O olhar que ele dirige então a este homem, que havia encarnado todas as suas esperanças, é agora terrível: "Sentimo-lo amargo, não se consolando de te jogado mal, mas solidarizando-se com o seu fracasso, assumindo-o, transformando a sua humilhação em orgulho e dizendo um pouco mais frequentemente do que seria necessário: - Eu que sou vichysta. Presente inesperado. Mas o tempo talvez tenha parado para ele na época em que podia ainda agir sobre o destino dos outros e sobre o seu próprio. De resto, sempre charmoso, ou antes sedutor, da mesma maneira enigmática que tinha outrora tanto prestígio a meus olhos. (...)

Enquanto ele fala, advogando a própria causa sem o parecer (o que faz que justamente o pareça), eu o revejo, entre dois policiais, diante de seus juízes, no dia em que eu fui testemunhar por ele... Ele me interroga sobre de Gaulle, com paixão, fazendome repetir que eu o acho de uma inteligência fora do comum, exigindo de mim detalhes sobre a sua maneira de ser. Sua mulher, igualmente curiosa, tenta me fazer avançar ainda mais na confidência. E eis aqui o Bergery inteligente que eu conheci bem. Aquele cujas demonstrações parecem imediatamente convincentes. Mas o desenrolar da história não obedece a uma lógica tão rigorosa, tanto assim que ele se engana frequentemente (senão sempre)."

Naquela noite, Bergery se entrega às confidências falando longamente deste imenso país que, ontem, o fascinara. "Quando eu soube que a União Soviética estava afrouxando pouco que fosse a sua pressão, disse ele, pensei que o regime não poderia suportar esta suavização, por mais leve que fosse. Estive duas vezes na URSS e em tempos afastados um do outro para ter feito as correções necessárias. Muito bem! Este regime não pode manter-se senão por uma total imposição. Tudo se passa como se a democracia não nos fizesse mal (ou nos fizesse apenas uma mal relativo), porque o nosso organismo está habituado a ela, tanto que doses massivas de liberdade não têm efeito sobre nós, enquanto esta mesma democracia seria um veneno mortal numa dose homeopática num país como a URSS. Minha opinião é, de resto, que a democracia está, no mundo inteiro, condenada à morte, como veremos cedo ou tarde. A simples razão é 
estas palavras sucedem outras em que reaparece a ponta da orelha do pequeno lobo perdido que ele foi sob a Ocupação. A política de Vichy já não é desta vez glorificada por ele de maneira artificial, pela honra, mas defendida fanaticamente em virtude de uma adesão interior. E quando eu digo: política de Vichy, quero dizer a política dos vichystas da sua raça, e talvez mesmo apenas a sua. Eu escuto pouco, então. Seus partidos tomados me irritam à medida se se chocam com os meus."

Os anos passam e de repente a nova tumba. "Paris, quinta-feira, 30 de maio de 1974, escreve Mauriac em suas memórias. Após um desaparecimento, um apagamento, um esquecimento, de vários anos, Gaston Bergery morreu, há alguns meses, sem que eu tivesse sentido isso - já não era ele, já não era eu -, sem mesmo, e eu sinto remorso por isso, que eu escrevesse a Bettina. Algumas linhas nos jornais, quando ele teve, para tantos entre nós, tamanha importância."

A longa narração de Claude Mauriac acabou. Mas acho outras mais breves, mais detalhadas, que dizem ainda do lugar que Bergery teve para toda uma geração. Em 1959, na sua Autocritique, o sociólogo Edgar Morin ${ }^{8}$ contou sua adesão ao frontismo: "Eu tinha encontrado em La Flèche um sincretismo que reunia, aliás mui frouxamente, os sentimentos que se misturavam em mim: a fraternidade antifascista, a crítica libertária, o pacifismo, o racionalismo cético (a aceitação de perspectivas restritas), de modo que minha desordem interior se sentia confortável na desordem de La Flèche, ao mesmo tempo que encontrava aí uma impressão de ordem."

No decorrer do inverno de 38/39, Morin assistiu às reuniões dos estudantes frontistas: "O frontismo tinha-me aparecido como a adaptação mais humana às necessidades do século. Após setembro de 39, as chances dos frontistas foram aniquiladas, se é que alguma vez existiram. Eu mergulhei nos estudos.”

\footnotetext{
${ }^{8}$ Edgar Morin, Autocritique (Paris : Julliard, 1959).
} 
Em 23 de junho de 2010, encontrei Edgar Morin em casa de sua filha Irène, e ele me falou de seu passado. "Fui frequentemente às reuniões de Bergery, me disse ele. Eu estava inscrito então nas juventudes frontistas. Estava seduzido pelo homem que tinha um discurso rigoroso e não fazia gestos. Quando se lhe faziam elogios, ele parecia indiferente. Ele era sóbrio, rigoroso, racional, convincente. Não um orador qualquer."

Morin continuou entrando mais fundo na história: "Revi Bergery por acaso em 1963 com Maurice Clavel. Ele tinha envelhecido um pouco. Barbeado, magro, os traços bem marcados. Era uma personalidade. Quando eu lhe disse que estava nas juventudes frontistas, ele me disse: “E nós tínhamos razão!”

Após este encontro, continuei minha pesquisa. Ela me levou cada vem mais longe. Em cada etapa, eu encontrava homens e sua história. Nomes se ajuntavam à minha lista. Eram advogados, escritores, estudantes, alguns muito jovens, outros mais velhos. Lembro do chefe de polícia de Paris que, em 1968, deverá enfrentar as perturbações da primavera. "Com alguns camaradas, conta Maurice Grimaud", tínhamos adotado Gaston Bergery, brilhante fundador do Partido Frontista, que pretendia combater ao mesmo tempo o fascismo e o comunismo e cujo jornal La Flèche denunciava a onipotência oculta dos trustes." Maurice Grimaud após Claude Mauriac, Edgar Morin e tantos outros.

\section{Fotos sépia}

Meu caminho continuava. Em um livro de Jerôme d'Astier ${ }^{10}$, encontrei quem eu procurava. Este escritor é o filho de Emmanuel d'Astier de La Vigerie e de Louba Krassine, a segunda esposa de Gaston Bergery. Em páginas muito tocantes, Jerôme d’Astier evoca longamente a sua mãe. "Ela tinha dezesseis anos, escreve ele, quando ela conheceu um jovem advogado, deputado socialista francês. Ele tinha um jornal que se chamava La Flèche. Ela se casou com ele. Aos vinte anos, teve meu primeiro irmão, o do meio. Ela devia assistir aos banquetes da circunscrição. A Sarthe. As mulheres dos notáveis que lhe

\footnotetext{
${ }^{9}$ « Du bon emploi des fièvres de mai », entrevista de Maurice Grimaud com Hélène L'Heuillet e Stéphane Thibierge, La célibataire 7 (printemps 2003),133-144.

10 Jérôme d'Astier, Je parlerai de toi à mon ami d'enfance (Paris : Gallimard, 2008).
} 
falam das melhores variedades de ervilha. Ela não sabe o que responder. Ela os agradece por seus elogios a propósito de seu vestido Balenciaga. Vibrando os rr. Sorrindo com os olhos. Ela é uma curiosidade. A filha de um sanguinário, um bolchevique que segura uma faca entre os dentes ${ }^{11 . "}$

O jovem advogado se chamava Gaston Bergery. Seu segundo casamento com a filha do primeiro embaixador na França da nova URSS foi um magnífico lance de pôquer que aumentou consideravelmente o seu prestígio na esquerda francesa. Bergery fora à pátria do comunismo. “Ela me dirá, conta d'Astier ${ }^{12}$, que voltou à Rússia em 1925, com seu primeiro marido, o jovem deputado socialista. Ela estava sozinha no camarote oficial do Bolshoi, uma noite, quando um homem entrou. Ela reconheceu o camarada Stalin, que a cumprimentou e questionou muito educadamente, fixando nela os olhos. Ele parecia uma raposa. Sob o raio $X$ do seu olhar, ela respondeu. Ele pedia notícias de seu pai, que estava muito doente, em Londres. Ele tinha algo de levemente opressivo. Os olhos. A voz aduladora. Uma impressão desagradável.”

O itinerário familiar me pareceu um caminho interessante. Então procurei no catálogo telefônico e acabei por colocar as mãos no número de telefone de um dos netos. Liguei para Benjamin Bergery e marquei um encontro com ele em Paris para uma segunda-feira, dia 19 de outubro de 2009. Tínhamos combinado de nos encontrarmos às 16 horas na estação de Stalingrado. Mas no metrô, meu celular tocou. Ele me disse para ir a Jaurès. No alto das escadas, encontrei um homem da minha idade, alguns anos mais velho talvez, com um ar de artista triste. Ele me contou que trabalhava com fotografia e cinema. Instalados num terraço na frente do canal, ficamos olhando o movimento. Suas palavras eram raras. Houve muitos silêncios. Seu avô? Ele o vira apenas duas ou três vezes, e eles não receberam nada dele. Nada de documentos, cartas, objetos. Nada! De repente ele pegou uma câmera e tirou fotos. Fotos de mim! Mas ele não deixou que eu o fotografasse. Nós caminhamos ao longo do canal. Fazia frio apesar do sol. Então entramos num café. Ele me falou da guerra. "O que teríamos feito? Disse ele. Mas por que um homem tão inteligente quanto Bergery pôde enganar-se?”

\footnotetext{
${ }^{11}$ d'Astier, Je parlerai de toi à mon ami d'enfance, 38.

${ }^{12}$ d'Astier, Je parlerai de toi à mon ami d'enfance,137.
} 
Eu o deixei e voltei à minha pesquisa. Na primavera daquele ano, eu publicara uma ficção $^{13}$ na qual coloquei um certo Gaston B. B. como Bergery! Para compor o personagem, me servi de tudo o que eu tinha acumulado sobre ele. No dia 3 de julho de 2009, recebi este e-mail que transcrevo inteiramente.

"Senhor,

Li com grande interesse o seu romance Trois coupes de champagne, em particular o capítulo 'Moscou', no qual o senhor conta o retorno à França do pessoal da Embaixada após a declaração de guerra da Alemanha à URSS. Em 1941, fiz parte deste pessoal na qualidade de secretário de Eirik Labonne ${ }^{14}$, depois de 'Gaston B.' e, em maio e junho, tive de substituir o cifrador que saíra em férias. As ‘equipes de decifradores' às quais o senhor faz alusão se reduziam à minha modesta pessoa!

Tendo feito com todo o pessoal diplomático a viagem - muito movimentada! - da qual você me oferece um quadro, conheci certamente a pessoa que Iha narrou. Seria indiscreto pedir-lhe que me dê o nome e o endereço desta pessoa? Eu ficaria muito contente... se ainda é tempo... de poder encontrá-la para evocar com ela estas lembranças longínquas...

Agradecendo-lhe muito, antecipadamente, pelo encaminhamento que o senhor desejar dar a esta mensagem, peço-lhe, senhor, que creia nos meus distintos sentimentos.

Denise HERSTANT, nascida DUPONT (é o sobrenome que eu usava em 1941).”

Eu a encontrei no dia 21 de setembro de 2009 em Bayonne, onde ela mora. Este momento foi excepcional. Durante horas, escutei com entusiasmo a narração que ela e seu marido me fizeram desses anos. Ela descreveu Bergery: "Um personagem muito desconcertante com um olhar muito frio. Mas ele não era de modo nenhum frio comigo. E era até divertido. Ele não era um diplomata qualquer, fazia brincadeiras." Ele concluiu

\footnotetext{
${ }^{13}$ Yves Pourcher, Trois coupes de champagne (Paris: Grasset, 2009).

${ }^{14}$ Eirik Labonne, embaixador da França em Moscou (12 de junho de 1940-abril de 1941).
} 
com o seu fim: "Em 1974, a missa de enterro aconteceu em Sainte-Clotilde. A igreja estava cheia. Eu encontrei camaradas de Moscou que eu tinha perdido de vista."

Quem era afinal este homem chamado Gaston Bergery? Eu tinha acumulado até então as referências livrescas e citado alguns testemunhos que às vezes se contradiziam. Como se as lembranças embaralhassem a verdade e apagassem o passado. Mas esta necessidade artificial de vida tinha-me afastado de meus primeiros passos. Para dar cor à foto do personagem, abri as pastas nas quais eu colocara meticulosamente meus documentos de arquivos. Sombrios demais! Pensei então, recortados e dispersos demais. Contudo, uma vez mais, estendi a mão e os peguei. Exumei páginas que vinham de lugares diferentes. Desde então, a minha pesquisa se aparentou a uma viagem. Peguei o avião, o trem, o metrô. A cada porta que eu batia, encontrava momentos de vida. Para fazer-me bem entender, indicarei precisamente os endereços e as instituições. Pois cada uma dentre elas conserva um momento desta vida.

\section{Castelo de Vincennes}

Eu pedi de oficial" 15 "BERGERY Gaston-Franck" estava escrito na capa do dossiê. Anotei algumas informações. "Jovem soldado chamado bom sérviço exército da classe de 1914 da subdivisão do Sena". Sua descrição: cabelos loiros, olhos azuis acinzentados, rosto ovalado, altura $1 \mathrm{~m} 75$.

No dia 2 de setembro de 1914, Bergery foi incorporado no $117^{\circ}$ regimento de infantaria. Ele foi para o exército no dia 28 de outubro. Nomeado cabo no dia $1^{\circ}$ dezembro, tornou-se sargento no dia 27 do mesmo mês, e depois aspirante no dia 21 de fevereiro de 1915. No dia 3 de março de 1915, foi citado na ordem do Corpo do exército: "Deu mostras de uma energia e de um vigor admirável ao treinar a sua tropa para o assalto durante o dia e o contra-ataque da noite de 23 de fevereiro."

Bergery foi ferido no dia 29 de setembro de 1915 na Epine de Videgrange, em Champagne: contusões múltiplas em razão dos estilhaços da bala de canhão. No dia 10 de

\footnotetext{
${ }^{15}$ Service historique de l'armée de Terre 8Ye 109716
} 
abril de 1916, entrou no hospital de Bordeaux, donde saiu no dia 14. Foi então levado para a ala dos convalescentes da caserna Faucher, em razão de problemas cerebrais e oculares por explosão de bala de canhão.

No dia 17 de junho de 1916, Bergery partiu para o Havre, na missão militar francesa junto do exército britânico. Ele serviu como oficial intérprete de 13 de setembro de 1918 a 12 de fevereiro de 1919, data na qual foi posto à disposição do ministro para o serviço da Conferência da paz. Sua missão se concluiu em 30 de agosto de 1919. No dia seguinte, ele foi desmobilizado.

Bergery foi nomeado subtenente no dia 13 de setembro de 1918. Tornar-se-á tenente no dia 8 de maio de 1924 e capitão no dia 25 de dezembro de 1933. Sempre bem visto, Bergery não será mobilizado em 1939.

Tudo me parecia perfeito. Bom soldado, suboficial, depois oficial distinto, notável pela coragem, culto e eficaz. Mas, de repente, o conteúdo do dossiê mudava de sentido. Uma pilha de notas e de relatórios denunciava a atividade pacifista e as opiniões políticas de Bergery. "Prepare a revolta contra o governo e a guerra civil", estava escrito precisamente. Inquéritos foram abertos. Bergery foi até mesmo ameaçado de prisão. No dia 17 de maio de 1934, o general de divisão Pretelat escreveu ao Marechal da França, ministro da Guerra: "Tenho a honra de propor que este oficial de reserva seja trazido perante um Conselho de inquérito com vistas à dispensa por falta grave contra a disciplina."

O Marechal da França se chamava Philippe Pétain.

\section{Cais de Orsay}

Nos arquivos do Ministério dos Assuntos Estrangeiros, encontrei o dossiê pessoal de Gaston Bergery, embaixador da França de Vichy, lotado em Moscou no dia 5 de abril de 1941, depois em Ancara no dia 16 de junho de 1942. Estava indicada a sua entrada na função, seu salário e o estado dos prédios que ele tinha ocupado. Todos os dias, "Sua 

às 23h:50:

“Cheguei esta manhã a Istambul, onde fui saudado na estação por nosso encarregado dos negócios, o cônsul geral e todos os membros representativos da colônia. Parto amanhã à noite, sexta-feira, para Ancara, onde iniciarei imediatamente o serviço. Bergery."

Outra mensagem enviada de Istambul, no dia 2 de setembro de 1942:

"Tendo-me convidado o Sr. von Papen na semana passada a almoçar privadamente na Therapia, fiz-lhe hoje esta gentileza. Ele almoçou no Palais de France com a Sr. ${ }^{\text {a }}$ von Papen e suas três filhas. É impossível mostrar mais consideração e simpatia do que ele me mostrou. Falou-me das coisas da França em termos que me emocionaram. Eu estaria tentado a acreditar que esta amabilidade fosse excepcional, se o Sr. von Papen não tivesse a reputação de ser um homem sempre excepcionalmente amável. Após o jantar, nós nos retiramos para o meu escritório e falamos a sós sobre todas as questões nas quais, na Turquia, os interesses da França e da Alemanha estão simultaneamente comprometidos. Sobre todas essas questões, nós realisamos um acordo completo."

Ernst von Papen é então embaixador da Alemanha em Ancara. Representante da direita católica em seu país, ele tinha permitido a chegada dos nazistas ao poder.

Há meses, a guerra se trava no leste, no meio da imensa URSS. A sorte da Europa e do mundo hesita. No seio da embaixada, alguns fazem escolhas, e Bergery reage e bate. Ele demite colaboradores. No dia 2 de setembro de 1942, ele escreve ao Ministério para propor cassações de nacionalidade. Os nomes se alinham em suas cartas com os motivos das sanções propostas:

“JOUVE Géraud, chefe dos Gaulistas da Turquia, está estabelecido na embaixada da Inglaterra, entrega vistos para a Turquia. Antigo correspondente da Agência Havas em Berlim, adido de alemão. 
MANAC'H Étienne-Manoël, professor adjunto do ensino secundário em GalataSaray, adjunto de Jouve.

MOUSSAT Édouard-Constantin, principal redator do boletim gaulista da Turquia.”

Alguns dias depois, em papel timbrado da Embaixada da França na Turquia, Bergery escreve: "Juro fidelidade à pessoa do Chefe do Estado e me comprometo a exercer meu cargo para o bem do Estado segundo as leis da honra e da probidade ${ }^{16}$."

$\mathrm{Na}$ mesma manhã, ele completou um texto do Ministério dos Assuntos Estrangeiros: "Sobrenome: Bergery. Nome: Gaston. Eu, subescrito, declaro sob a fé do juramento, nunca ter pertencido, em qualquer que fosse a condição, a qualquer das seguintes sociedades: Grande Oriente da França, Grande Loja da França, Grande Loja Nacional Independente, Ordem Mista Internacional do Direito Humano, Sociedade Teosófica, Grande Priorado das Gálias, a qualquer das filiais das ditas sociedades, ou a qualquer outra sociedade visada pela lei de 13 de agosto de 1940, e me comprometo, pela honra, a nunca fazer parte delas, caso elas viessem a reconstituir-se diretamente ou não."

Uma coleção intitulada Papiers Bergery, "a coleção do embaixador”, reúne os telegramas expedidos e recebidos pelo posto de Ancara. Vinte e sete fotos sobre a vida na embaixada completam o todo. Vê-se aí Bergery de terno branco e sua esposa de vestido elegante, recebendo, visitando, subindo num iate. Os conservadores, que apresentam os documentos, dizem que não se sabe em quais circunstâncias esses papéis foram dados aos Arquivos Diplomáticos. Quando exatamente Bergery remeteu esses documentos?

Eu lia impacientemente todos os folhetos, anotando todas as nuanças que se estabeleciam nas relações. Elas me pareciam atravessadas pelos mal-entendidos, os subterfúgios ou as exprobrações. Contudo, uma mesma política de falência ou de comprometimento se aplicava tanto bem, quanto mal. No dia 15 de setembro de 1942, às 11h:10, o chefe do governo de Vichy tinha escrito: “Eu me refiro ao seu telegrama 1202-12. Confio plenamente em você na tarefa de depuração e de união que você assume e cujas

\footnotetext{
${ }^{16}$ Istambul, 22 de septembro de 1942. A carta está assinada por Gaston Bergery, Embaixador da França.
} 
dificuldades eu conheço. Faço de minha parte o necessário para agilizar as formalidades de cassação de nacionalidade requeridas pelo seu telegrama de 1134-41. Pierre Laval."

Bergery aplicava, pelo menos aparentemente, as novas leis, mesmo as mais sórdidas. No dia 12 de janeiro de 1943, ele solicitou precisões por telegrama: “Eu agradeceria ao Departamento se me fizesse saber se a mulher judia francesa de um marido ariano e francês pode, nas condições atuais, receber um visto de saída da França para encontrar o seu marido no estrangeiro. Faço essa pergunta apenas por princípio e sob a reserva, está claro, de casos específicos."

Todos esses documentos juntos mostram o comprometimento, a ambiguidade e o aumento dos perigos. Bergery era um homem de Vichy. Mas ele sabia também ver e escutar. Em seguida, contava o teor das suas entrevistas. Em suas cartas, eu destacava nuanças, evoluções e deslizamentos. Onde passa a fronteira entre a fidelidade a este ignóbil regime e o distanciamento? O arquivo revela às vezes um lento caminho. Assim, no dia 21 de julho de 1944 chegou à embaixada uma mensagem que traduzia o descontentamento": "Recebi a carta que você enviou no dia 11 de junho ao Sr. Selim Saper para protestar contra o artigo do 'Yeni Sabah' de 9 de junho. Li o artigo. Ele me visa e me injuria tanto quanto o Marechal. Você teve razão em protestar. Lamento somente que você me tenha omitido em seu protesto. Se, pessoalmente, desprezo os insultos, lembro que na França a legislação pune as injúrias que visam os Ministros dos Assuntos Estrangeiros, tanto quanto os Chefes do Estado."

A carta estava assinada por Pierre Laval.

O fim da guerra se aproximava. Após a liberação da França, Bergery deixou a embaixada, permanecendo, contudo, prudentemente na Turquia. Do seu refúgio, sua esposa Bettina enviou uma correspondência a uma amiga: "Eu Ihe escrevi quando deixamos, em abril, o Park-Hotel para nos fixarmos nesta costa da Ásia. Desde então esperamos em uma agradável casinha com um grande jardim e um riozinho com um pequeno veleiro, esperamos um barco maior que nos reconduzirá a nossa casa. Que espera longa desde o mês de setembro. Gaston tem as malas cheias de documentos de

\footnotetext{
${ }^{17}$ Ele tinha sido enviado de Vichy em 14 de julho de 1944.
} 
todas as missões. Ele deve levá-las consigo, pois não pode deixar que os oficiais aduaneiros as leiam e não pode arriscar tampouco que as confisquem na viagem. Eis por que esperamos um barco direto para a França, francês ou turco. Até agora, não havia senão um cargueiro que não recebeu passageiros. Há alguns meses, Gaston escreveu ao General de Gaulle, e explicou a situação. Ele pediu um meio de levar seus documentos como bagagens pessoais assim que possível. Até agora, nenhuma resposta ${ }^{18}$."

Um barco havia passado. Os Bergerys tinham voltado à França.

\section{Rua dos arquivos}

Nos documentos do processo conservados nos Arquivos Nacionais ${ }^{19}$, encontrei primeiramente uma nota individual da direção geral da segurança nacional. Um homem era apresentado. Sua altura, 1m72, com a barba feita. Ele fora advogado, político e depois embaixador. Sua situação militar: capitão de reserva. Por mandado do Sr. Marchat, juiz de instrução na Corte de Justiça do Sena, Gaston Bergery foi preso no dia 25 de outubro de 1945 e logo em seguida incriminado de ligação com o inimigo.

Os interrogatórios começaram no dia 26 de outubro. Estão datilografados em folhas de papel-bíblia anotadas e sublinhadas. Bergery volta à sua juventude, sua carreira política, suas embaixadas. Ele acumula detalhes sobre seus atos, suas frequentações e advoga a sua causa.

As audições se sucederam. Transcrevo a que aconteceu no dia 29 de outubro de 1945, enumerando as perguntas que foram feitas:

"Você fez viagens ao estrangeiro, sobretudo à Alemanha, antes da guerra e sob a Ocupação?"

"Como e em quais circunstâncias você entrou em relações frequentes com o Marechal Pétain?”

\footnotetext{
${ }^{18}$ Carta de Bettina Bergery a Miss Alice de Samar, Av. Park, 530, New York, em 5 de junho de 1945

${ }^{19}$ Arquivos Nacionais F7/15326.
} 
“Você assistiu a uma recepção organizada no dia 8 de dezembro de 1941, por Goering, em Paris?"

"Na condição de embaixador da França em Ancara, você foi chamado a solicitar sanções contra membros da colônia francesa."

As respostas seguem e terminam todas pela mesma fórmula: "feita a leitura, confirma e assina, o delegado de polícia (...).

A justiça vasculhava o passado de Bergery. Ela buscava fixar seu papel durante a Ocupação. Ele reconheceu que encontrou Abetz em Paris seguindo as instruções do marechal, sem se arrepender de sua atitude. Nos dias seguintes, o interrogatório continuou. Eu virava as páginas desses arquivos de um processo político. Enfim, no dia 12 de fevereiro de 1949, às 22 horas, a primeira seção da Corte de Justiça do Sena proferiu seu julgamento, dos quais reporto as principais conclusões:

“Primeira questão. Gaston Bergery, acusado aqui presente, é acusado de ter, na França e no estrangeiro, de 1940 a 1944, em todos os casos entre 16 de junho de 1940 e a data da liberação, em tempo de guerra, sendo francês, mantido ligações com uma potência estrangeira ou com seus agentes, em vista de favorecer os empreendimentos de todas as naturezas dessa potência estrangeira contra a França, ou qualquer das nações aliadas em guerra com as potências do eixo."

Resposta: não à maioria.

Seguem outros complementos: ele não prejudicou a defesa nacional; não era culpado de indignidade nacional. Em consequência, Gaston Bergery se beneficiou de uma absolvição pura e simples ${ }^{20}$.

Após este veredito e para ir mais longe, eu percorria inventários. Buscava nas diversas séries. Em um microfilme, li o jornal de Marcel Déat ${ }^{21}$, que tinha sido um dos responsáveis mais encarniçados da política da Colaboração. O nome de Bergery aparecia várias vezes. Eu agarrava suas aparições como flashes, jatos de luz no meio dos arquivos

\footnotetext{
${ }^{20}$ Arquivos Nacionais AL/5299.

${ }^{21}$ Arquivos Nacionais F7 15342.
} 
sombrios. Eles testemunhavam um momento, uma atitude ou um pensamento. A silhueta de Bergery se animava. Seus lábios se mexiam, seu corpo avançava. Eu o via, ouvia-o. Após a ruptura das relações diplomáticas com a URSS, como consequência da declaração de guerra da Alemanha contra esse país, ele tinha voltado à França. "Quinta-feira, 20 de novembro de 1941, escreve Déat. (...) Chegada de Bergery: declarações interessantes sobre o exército de robôs, sobre o massacre das elites, sobre o terror de Stalin diante da guerra, sobre os incidentes pitorescos da última semana antes da ofensiva alemã, sobre a viagem de retorno e o acidente de trem."

Alguns dias depois, Goering era recebido em Paris e Déat conta: “Terça-feira, 2 de dezembro de 1941 (...) Retorno à casa. As pessoas se preparam para a recepção, vestindo smoking. Às 9h:15 fomos no carro de L'Oeuvre ${ }^{22}$ com Prieur. Noite sensivelmente como a da segunda-feira, com mais pessoas e uniformes. Chegada do marechal, apresentação. Conversa-se em todos os cantos. Buffet suntuoso. Laval fala um pouco com Goering. Abetz quer também que eu fale com o Marechal, mas é tarde demais. E aliás, por que dizer? Bergery é visto em uniforme de embaixador, com Bettina. Schueller é visto, a Sr. ${ }^{a}$ Fontenoy, a Sr. ${ }^{\text {a }}$ Lacombe, Paul Morand, du Jonchet, Arletty, os de Chambrun, Monsenhor Mayol de Lupé, etc, etc., e naturalmente uma multidão de alemães civis e militares. Voltamos a pé à luz da lua, e Prieur vai se apoiando na travessia da metade de Paris."

Bergery se apresentou em traje a rigor na embaixada da Alemanha. Ele gostava tanto disso.

Saí deste lugar com a dúvida e o desgosto na cabeça. Até onde Bergery tinha ido no seu comprometimento? E depois eu me interrogava para saber se eu não tinha omitido nada. Eu tinha passado por tudo? Não tinha deixado nada de lado?

\section{Novas pistas}

Fui aos arquivos da prefeitura de polícia de Paris onde não encontrei nada. Bergery não tinha nem ficha nem dossiê. Então, não sabendo mais qual caminho seguir, voltei-me

\footnotetext{
${ }^{22}$ L'Oeuvre, jornal dirigido desde julho de 1940 por Marcel Déat.
} 
para os meus próprios arquivos, abrindo as caixas nas quais eu havia posto as notas que tomei entre 1994 e 1997 no grande apartamento de Josée de Chambrun²3, a filha única de Pierre Laval. Reli suas agendas íntimas ${ }^{24}$. Os Chambruns e os Bergerys tinham recebido muito durante a Ocupação. No dia 15 de outubro de 1945, Laval tinha sido fuzilado, e, nos anos seguintes, sua filha e seu genro construíram em torno de si uma espécie de capela dos fiéis de Vichy. Contudo, os rancores eram numerosos neste mundinho de nostálgicos e amargurados. Em pleno processo, o advogado René de Chambrun escreveu a Bergery para lhe dizer em termos nuançados seu descontentamento:

“Meu caro Gaston,

Eu estava na audiência hoje e aprovei e apreciei muitas coisas que tu disseste; mas permite-me fazer-te notar muito afetuosamente:

$1^{\circ}$ - que o meu sogro nunca aspirou a fazer guerra contra a Grã-Bretanha. Ser-te-á suficiente, para te convenceres disso, ler o texto desta carta que Josée escreveu recentemente ao Sr. Paul Baudoin ${ }^{25}$.

$2^{\circ}$ - que 'a alternativa' para o meu sogro de te enviar a Ancara ou de te colocar 'no xilindró' nunca se colocou? Foi à Josée que vieste pedir, em abril de 1942, o posto de Ancara. Fui eu quem foi teu embaixador para obtê-lo e tu foste lá - juro pela memória do meu sogro - com sua inteira confiança. Com muito afeto a ti. ${ }^{26 "}$

A resposta não demorou. "1 hora, notara Josée na sua caderneta Hermès no dia 14 de fevereiro de 1949, Bergery para me contar o seu processo, resolver as coisas e oferecer as desculpas." As relações se apaziguaram. Nesta época, os Bergerys frequentavam um personagem muito sombrio, Oswald Mosley, que, nos anos que precederam a guerra, tinha sido o líder dos fascistas ingleses. "Agradável almoço em casa dos Mosleys ontem com os eternos Bergerys", escrevia Josée a seu marido no dia 19 de abril de 1956. Suas relações eram também mundanas.

\footnotetext{
${ }^{23}$ Na Praça do Palais-Bourbon, 66, em Paris.

${ }^{24}$ Yves Pourcher, Pierre Laval vu par sa fille (Paris : Le cherche midi, 2002) e Yves Pourcher, « Laval museum ", Historical reflections 38, 1 (2012), 105-125.

${ }^{25}$ Paul Baudoin, ministro dos Assuntos Estrangeiros, de 16 de junho a 29 de outubro de 1940.

${ }^{26}$ Arquivos privados da Fundação Josée e René de Chambrun, carta de 7 de fevereiro de 1949.
} 
Eu percorria as bibliotecas. Em um grande livro intitulado Journal de France, que reúne as agendas de Angelo Giuseppe Roncalli ${ }^{27}$, núncio apostólico em Paris, encontrei o nome de Bergery. Os dois homens se conheceram na Turquia e gostaram um do outro. No dia 27 de abril de 1946, precisamente, o núncio recebeu o advogado de Bergery que colhera o seu testemunho em seu favor. E após a sua liberação, nos dias 30 de abril e $1^{\circ}$ de junho de 1948, Gaston Bergery foi logo ao encontro do prelado. "O embaixador Bergery, anotou Roncalli na sua caderneta, que me instou muito a ajudá-lo." Bergery obteve uma nova audiência no dia 23 de outubro. "Oh! Como o mundo político é traidor, escreveu o núncio. Ele não perdoa ninguém. Para mim, Bergery é uma alma para ajudar.” Nos meses e nos anos seguintes, os dois continuaram a se frequentar.

Em outra prateleira, encontrei o Journal inutile, do escritor Paul Morand ${ }^{28}$, outro embaixador de Vichy. No dia 15 de fevereiro de 1974, ele anotou o fim: "Morte de Bergery aos 80 anos. Ele era apoplético fazia 10 anos. Fim lamentável, como quase todos. Eu o conhecera em 1924. Ele conquistara Herriot ${ }^{29}$. Suas recepções em um estúdio decorado e mobiliado na morte de Ruhlmann, em torno de 1925. Depois, na sociedade. Ele encontrou Bettina em Nova Iorque, antes do seu casamento, em 27, ainda manequim. Depois do período fascista de La Flèche, em 36-40. Reencontrado em Vichy em42. O primeiro a me dizer: 'Os russos ganharam, os Alemães estão perdidos.' Embaixador em Ancara, ele veio com Bettina passar alguns dias em nossa casa, em Bucareste, em 1944."

Deixei as bibliotecas e as livrarias. Contudo, uma questão não deixava o meu espírito em paz. Tinha eu ido até o fim dessa história? Em realidade, eu sabia bem que existiam outros documentos, longínquos, quase inacessíveis. O historiador Philippe Burrin os havia consultado. Como alguns outros indivíduos ligados ao regime de Vichy e à Colaboração, Gaston Bergery tinha dado, antes da sua morte, seus arquivos pessoais à fundação Hoover, situada em Stanford ${ }^{30}$. Escrevi então para este endereço. Após várias

\footnotetext{
27 Angello Giussepe Roncalli, Journal de France. I 1945-1948 (Paris : Cerf, 2006). Monsenhor Roncalli se tornará papa sob o nome de João XXIII em 1958.

${ }^{28}$ Paul Morand, Journal inutile. 1973-1976 (Paris : Gallimard, 2001), 190-191.

${ }^{29}$ Gaston Bergery tinha sido chefe de gabinete de Edouard Herriot no Ministério dos Assuntos Estrangeiros (1924-1925).

30 René de Chambrun tinha lançado o movimento. Sob a égide desta fundação, ele tinha reunido os
} 

escritos pessoais. No mês de maio de 2011, cheguei enfim à pequena estação de Palo Alto, depois caminhei em direção da torre Hoover. Entrei no escritório de Linda Bernard, a conservadora. Ela me apresentou a fundação, depois me falou dos documentos de Bergery, que tinham sido classificados e organizados meticulosamente. Ele estava aberto. Mas eu devia vir trabalhar no local. Algumas horas depois, retomei meu trem em direção de San Francisco, prometendo a mim mesmo voltar logo.

Entrei na França e, algumas semanas depois, como eu fazia frequentemente, escrevi o nome de Bergery no meu teclado. Descobri então que a universidade de Yale tinha adquirido, em 2002, os documentos pessoais de Bettina ${ }^{31}$. O inventário indicava trinta caixas, incluindo suas agendas, livros, cartas e anotações. No site, eu a vi numa foto, vestida com um vestido magnífico de noite, ou num traje de esqui, e ele, Gaston, trazendo o uniforme de embaixador. Um novo mundo se abria, o qual me parecia inacessível. Logo sem seguida, e como frequentemente no decorrer de minhas aventuras nos arquivos, a figura do labirinto me aparecia. De todos os lados, ela lançava as suas rotas, seus caminhos, suas sendas, que se cruzavam e se superpunham. Como eu devia fazer para os seguir? Estava eu simplesmente preso na armadilha ordinária da biografia ou esta vida, a de Gaston Bergery, me pregava uma peça? Contudo, eu me encarniçava, comprando lotes de exemplares de La Flèche, o jornal de Bergery, que eu lia pacientemente. Encontrava aí seus discursos, suas declarações políticas e seus artigos polêmicos. A atualidade política desses anos trinta desfilava através dessas páginas. Em sites especializados, eu encontrava também textos que falavam dele e fotos. Mas isto não me era suficiente.

\section{Labirinto}

testemunhos dos colaboradores do seu sogro, Pierre Laval.

${ }^{31}$ Yale University Library, Beinecke Rare Book and Manuscript Library. General Collection of Modern Books and Manuscripts. Guide to the Bettina Bergery Papers GEN MSS 844 by Karen Spicher, August 2012 
Havia vários meses, eu entrara em relação com um jornalista, escritor e homem de televisão: Jean-José Marchand ${ }^{32}$. Entrei em contato com ele um pouco por acaso, porque no mesmo momento eu pesquisava sobre outro personagem, um indivíduo tão inacessível quanto Bergery ${ }^{33}$. Os arquivos municipais de Arcachon me deram um número de telefone que eu anotei prontamente. Jean-José Marchand me escutou pedindo-me que eu lhe enviasse alguns de meus livros. Desde então, eu lhe telefonava regularmente. Ele me falava do entreguerras, do período da Ocupação e me guiava em minhas pesquisas.

Jean-José Marchand sabia tudo. Quando ele me falava de sua idade, "quase centenário", dizia ele exagerando, era para acrescentar logo em seguida: “O único mérito de ser velho é ter visto o que fizeram os outros ${ }^{34}$." Ele conhecia perfeitamente a vida de Bergery. "Um personagem totalmente notável que tinha uma visão", comentava. "E que tinha muito gosto", acrescentava. Jean-José Marchand conheceu seu filho, Jean-François, roteirista de profissão, "um rapaz muito bonito que tinha casado como uma Americana muito bonita". Mas sobre seu pai, Marchand disse algumas palavras definitivas que continuam ainda hoje muito estranhas: "A história o enganou como uma má professora 35 . Era essa a conclusão desta história? Uma noite, contudo, eu peguei novamente o livro de Jérôme d'Astier. “O passado é como um colar de pérolas partido”, escrevera. Mas essas pérolas se dispersaram? Contra ventos e marés, conseguiram elas manter suas cores e seus segredos? E eu, neste caminho, não me perdi?

Contudo, na noite ${ }^{36}$ mesma em que, em Toulouse, eu apresentei este Dossiê Bergery perante um pequeno grupo de colegas, foi anunciado nos muros da cidade um grande encontro político. A campanha para as eleições presidenciais animava já havia

\footnotetext{
32 Jean-José Marchand (1920-2011). Pode-se ler dele, recentemente publicados, Jean-José Marchand, Écrits critiques (Paris : Éditions du Félin-Éditions Claire Paulhan, 2012), 5 volumes numa caixa (dos quais o primeiro é o índex), 2910 páginas.

33 Tratava-se de Jean Fontenoy, personagem ácido, ex-jornalista da agência Havas, que afundou e morreu na Colaboração. Um livro recente trata de sua vida e do seu percurso: Gérard Guégan, Fontenoy ne reviendra plus (Paris : Stock, 2011).

${ }^{34}$ Conversa telefônica de quinta-feira, 10 de setembro de 2009.

${ }^{35}$ Conversa telefônica de 22 de setembro de 2009.

${ }^{36}$ Quinta-feira, 5 de abril de 2012.
} 
meses o debate público. Na grande praça do Capitólio situada no coração da cidade, fui ouvir Jean-Luc Mélanchon, candidato da Frente de Esquerda. "Nesta estação de tempestades que caem sobre o mundo, escreveu ele no seu folheto, é a hora dos caracteres. Demos o melhor de nós mesmos para enfrentar. Somos capazes de vencer todas as dificuldades. A felicidade comum é possível." Seu texto continuava com um apelo ao povo soberano. "Venha o tempo das cerejas e dos dias felizes!", concluiu.

Avançando rumo à praça, vi a multidão ${ }^{37}$ que pouco a pouco se formava. Alguns seguravam nas mãos bandeiras vermelhas. O encontro era a céu aberto. Os discursos começaram. Oradores aqueceram a praça. Depois, ele subiu ao palanque de terno preto, camisa branca e gravata vermelha. Começou saudando Jean Jaurès, um filho desta região. Depois, durante trinta minutos, Jean-Luc Mélanchon conclamou à revolta contra os poderosos, sendo que os ricos também gritavam contra o presidente que estava de saída. A Internationale e a Marselhesa foram cantadas. As pessoas se dispersaram sob a chuva que se pôs a cair ${ }^{38}$.

Eu me afastei com essas palavras e essas imagens que ressoavam em minha cabeça e punham um ponto final nesta interminável pesquisa. Ontem um fronte comum, com um homem chamado Bergery, e hoje um fronte de esquerda reunindo os comunistas e simpatizantes, e este novo líder de gravata vermelha. Então, pensei em todos esses homens que, nas dobras da história, procuram seu destino abrindo bem seus braços para a oportunidade que eles procuram e que acreditam ver vir.

\footnotetext{
3770000 pessoas, segundo os organizadores.

${ }^{38}$ Dia 6 de maio de 2012, dia do primeiro turno das eleições presidenciais, Jean-Luc Mélenchon obtém 3984 822 votos, ou seja, $11,10 \%$ do total.
} 
